\title{
Bir “Avrupa” Azınlığı Olarak Batı Trakya Türkleri
}

\author{
Gizem ALİOĞLU ÇAKMAK*
}

Öz

Batı Trakya Müslüman Türkleri, 1923’ten günümüze kadar pek çok sorunla ve ayrımcılıkla karșı karşıya kalmıș, özelikle Türk-Yunan ilişkilerinin Kıbrıs Sorunu sebebiyle bozulduğu 1970li yıllar sonrasında ayrımcıllğın ve sorunların şiddeti artarak devam etmiştir. Bu sorunların başında, etnik kimliğin reddi, eğitim, vatandaşlıktan ıskat, din ve vicdan hürriyeti ve buna bağlı müftülük sorunu, kurumların kontrolü sorunu, demografik yapının değiştirilmesi, ifade özgürlüğüne sınırlamalar gelmektedir. Ancak, 1990'ların son yarısında ve 2000'li yıllarda Yunanistan'da azınlık hakları konusunda olumlu gelişmeler meydana gelmiştir. Bu bağlamda, azınlığı mağdur eden tüm sorunların çözümü sağlanmasa bile bazı alanlardaki gelişmeler incelemeye değerdir. $\mathrm{Bu}$ çalışmanın amacı 1990'lardan itibaren Yunanistan'daki azınlık hakları konusunda Avrupalılaşma ve Avrupa kurumlarının etkisini analiz etmektir.

Anahtar Kelimeler: Batı Trakya, Azınlık Hakları, Avrupalılaşma, Yunanistan, Türk azınlık.

\section{The Turks of Western Thrace as a "European" Minority Group}

\section{Abstract}

The Turkish Muslim Minority in Western Thrace has been subject to discriminative practices and human right violations since 1923. Especially after the 1970s, when the Turkish-Greek relations deteriorated due to the Cyprus Problem, the situation for the Minority worsened dramatically. The most significant problems of the Minority are; the denial of ethnic identity, education, de-nationalization of the minority members, freedom of religion and the election of Muftis, the problem concerning the control of the Minority institutions, demographic changes, and the freedom of expression. Since the late 1990s and throughout the 2000s, considerable positive developments in minority rights have been taking place in Greece. Despite the liberalization of minority rights and softening of the discriminative measures and repressive policies, as the fundamental problems of Western Thrace Turks still persist, this process is worth examining. The aim of this study is to examine the role of

Özgün Araştırma Makalesi (Original Research Article)

Geliş/Received: 02.02.2018

Kabul/Accepted: 26.04 .2018

DOI: http://dx.doi.org/10.17336/igusbd.409435

* Dr. Öğr. Üyesi, Yeditepe Üniversitesi, İIBBF, Siyaset Bilimi ve Uluslararası İlişkiler Bölümü (İng.), İstanbul, Türkiye, E-posta: galioglu@yeditepe.edu.tr ORCID ID https://orcid.org/0000-0002-8860$\underline{0857}$ 
Europeanization and European Institutions on the minority rights in Greece starting with the 1990s. Minority.

Keywords: Western Thrace, Minority rights, Europeanization, Greece, Turkish

\section{Giriş}

Balkan Savaşları sonucu Osmanlı İmparatorluğu Avrupa'daki topraklarının neredeyse yüzde seksenini kaybetmiş ve nüfusu çoğunlukla Türk olan, Meriç nehrinin batısındaki "Batı Trakya” toprakları ilk önce Bulgaristan, sonrasında ise Yunanistan kontrolüne geçmiștir. Bu tarihten sonra, Batı Trakya Türklerinin kaderini tayin eden en önemli gelișme ise, Kasım 1922'de başlayan Lozan Konferansı'dır. Balkan Savaşları, Birinci Dünya Savaşı ve Yunanistan'ın Anadolu'yu işgali sırasında ve sonrasında yüz binlerce insan evlerini bırakarak göç etmek zorunda kalmış ve böylelikle hem Türkiye hem de Yunanistan'da ciddi bir göç sorunu ortaya çıkmıştır. İnsani boyutu nedeniyle, Lozan Konferansı'nda göçmenlerin geleceği ve nüfus mübadelesi en öncelikli konulardan biri olarak gündeme gelmiştir. Uzun müzakereler sonucu, 30 Ocak 1923 yılında, Türkiye ve Yunanistan arasında 'Yunan ve Türk Halklarının Mübadelesine İlişkin Sözleşme ve Protokol' imzalanmıștır. Bu protokole göre Türkiye'deki Ortodoks Rumlar ile Yunanistan'daki Müslümanlar zorunlu göçe tabi olacaklardır. Batı Trakya Müslüman Türkleri ve İstanbul Rumları bu ahali değişiminin dışında bırakılmış ve hakları Lozan Antlaşması'nın 37- 45. maddelerince belirlenmiştir. ${ }^{1} \mathrm{Bu}$ tarihten itibaren Batı Trakya Müslüman Türkleri Yunanistan Devleti'nin vatandaşı olarak, azınlık statüsünde bir topluluk olarak yaşamlarına devam ettiler. Batı Trakya Müslüman Türkleri, 1923'ten günümüze kadar pek çok sorunla ve ayrımcılıkla karşı karşıya kalmış, özelikle Türk-Yunan ilişkilerinin Kıbrıs Sorunu sebebiyle bozulduğu 1970li yıllar sonrasında ayrımcılığın ve sorunların şiddeti artarak devam etmiştir. Bu sorunların başında, etnik kimliğin reddi, eğitim, vatandaşlıktan ıskat, din ve vicdan hürriyeti ve buna bağlı müftülük sorunu, vatandaşlıktan iskat, kurumların kontrolü sorunu, demografik yapının değiştirilmesi, yasak bölge uygulaması, ifade özgürlügüne sınırlamalar gelmektedir. (Batı Trakya Türkleri Dayanışma Derneği, t.y.) Ancak, 1990'ların son yarısında ve 2000'li yıllarda Yunanistan'da azınlık hakları konusunda olumlu gelişmeler meydana gelmiştir. $\mathrm{Bu}$ bağlamda, azınlığı mağdur eden tüm sorunların çözümü sağlanmasa bile bazı alanlardaki gelişmeler incelemeye değerdir. Özellikle, 1998 yılında Yunanistan vatandaşlık yasasının ayrımcı 19. Maddesinin kaldırılması, Müslüman Türk gençlere üniversitelerde azınlık kotası sağlanması, yasak bölge

\footnotetext{
${ }^{1}$ Nüfus mübadelesinin ayrıntılı analizi için bakınız: Arı, K. (1995). Türkiye'ye Zorunlu Göç (19231925). İstanbul: Tarih Vakfı Yurt Yayınları; Hirschon, R. (2005). Ege'yi Geçerken: 1923 Türk-Yunan Zorunlu Nüfus Mübadelesi. İstanbul: İstanbul Bilgi Üniversitesi Yayınları; Yıldırım, O. (2006). Diploması ve Göç: Türk-Yunan Nüfus Mübadelesinin Öteki Yüzü. İstanbul: İstanbul Bilgi Üniversitesi Yayınları.
} 
uygulamasının sonlandırılması, pratikte olmasa da kâğıt üzerinde memuriyet yolunun açılması ve bazı siyasilerin yumuşayan söylemleri bu iyileştirme politikası içerisinde ele alınabilir. Bu dönemle ilgili yapılan araştırmalara bakıldığı zaman azınlık hakları konusundaki olumlu gelişmelerin Yunanistan'ın Avrupalılaşmasına paralellik gösterdiğini tartışan çalışmalara rastlamak mümkündür. ${ }^{2}$ Aslında bu dönemde meydana gelen olumlu gelişmeler ve iyileştirme politikaları sadece Avrupa etkisiyle açıklanamayacak kadar çok boyutlu bir süreçtir. Batı Trakya Müslüman Türklerinin özellikle 1980'lerle beraber artan hak taleplerini ve sorunlarını uluslararası platforma taşımadaki başarıları, anavatan olarak Türkiye'nin rolü, Türk- Yunan ilişkilerinde 1999'dan itibaren yakınlaşma sürecine girilmesi, Yunanistan'ın 90'lı yılların ikinci yarısında hızlı bir Avrupalılașma sürecine girmesi, ve Avrupa'da azınlıklara gösterilen hassasiyetin artması bahsedilen olumlu gelişmeler üzerinde etkin olan faktörlerdir. $\mathrm{Bu}$ çalışma bahsedilen unsurlardan Yunanistan'ın Avrupalılaşma süreci ve azınlık haklarının iyileştirilmesi konusunda Avrupa kurumlarının etkisine odaklanmaktadır. Bu makalenin amacı belirtilen etkenler arasından Yunanistan'ın Avrupalılaşma sürecinin ve Avrupa kurumlarının azınlık haklarına etkisini analiz etmektir. Özellikle, Yunanistan'da Avrupalılaşma için önemli bir tarih olarak nitelendirilebilecek olan 1996 yılı sonrası gelişmelere değinerek Yunanistan'ın Avrupalılaşması ile azınlık haklarına yansıyan somut gelişmeler arasındaki ilişki incelenecektir.

Yunanistan, Avrupa Ekonomik Topluluğu'na 1981'de üye olmuştur. Üye olduğu yıllarda, siyasi kültürü, zayıf ve gelişmemiş ekonomisi, dört yüz yıllık Osmanlı mirası, Güney doğu Avrupa'daki stratejik konumu ve Ortodoks inancıyla, topluluktaki diğer ülkelerden farklı özelliklere sahiptir. Bu özellikleri göz önündeki bulundurulduğunda Yunanistan'ın Avrupalılaşma süreci incelemeye değer, uzun bir süreçtir. Yunanistan, uzun yıllar Batı Avrupalı ortaklarından kendini ayırarak, Avrupa Topluluğu içinde kuvvetli bir 'öteki' algısıyla hareket etmiştir. 1981'de tam üyelik kazanmasının ardından dış politikasındaki milliyetçi söylemler, Avrupa kural ve normlarına gösterdiği direnç ve geri kalmış ekonomisiyle Avrupa'nın "kara koyunu" olarak görülmüştür (Clogg, 1993). Bir Avrupa ülkesi olmaktan ziyade, milliyetçi dürtülerle hareket eden bir Balkan devleti konumundadır.

1996'dan beri Yunanistan hızlı bir Avrupalılaşma sürecine girmiş, Birlik içinde bir Balkan ülkesi olmak yerine Avrupalı bir aktör haline gelmeyi amaçlamıştır. Yunanistan'daki azınlık hakları konusunda, Avrupa'nın da baskısıyla, somut bazı iyileştirme girişimlerinin varlığı aşikârdır.

\footnotetext{
2 Bakınız: Grioriadis, I. N. (2008). On the europeanization of minority rights protection: comparing the cases of Greece and Turkey. Mediterranean Politics, Cilt 13 (1), s. 23-41; Onar, N. F., Özgüneş, M. (2010). Europeanization of Greek and Turkish minority policies. International Journal on Minority and Group Rights, Cilt 17 (1), s. 111-136; Anagnostou, D. (2005). Deepening democracy or defending the nation? The europeanisation of minority rights and Greek citizenship. West European Politics, Cilt 28(2), s. 335-357.
} 


\section{Teorik Çerçeve: Modernleşme Süreci olarak Avrupalılaşma}

Avrupalılaşma literatürü, yapılan çalışmaların sayısı ve başlıklarının çeşitliliği göz önünde bulundurulduğunda oldukça geniş bir çalışma sahasıdır. 1980’lerden önce Avrupalılaşma konusunda yapılan çalışmalar sınırlıyken, günümüzde alana ilgi giderek artmaktadır. Bu konuda yapılan çalışmaların yoğunluğu aynı zamanda bir anlam karmaşasını da doğurmaktadır. Kavramların ve tanımların içinde boğulmak bu alanda çalışanlar için bazen kaçınılmaz olmaktadır. Avrupalılaşma literatürüne ayrıntıları ile değinmek bu çalışmanın kapsamı dışında olduğundan bu bölümde yalnızca Yunanistan'ın Avrupalılaşmasının teorik yaklaşımla değerlendirmesi hedeflenmektedir.

Yunanistan'ın ve Güney Doğu Avrupa'nın Avrupalılaşma süreci birçok sosyal bilimci tarafından "modernleșme süreci" olarak tanımlanmaktadır (Ioakimidis, 2000, s. 74-75; Wong, 2011, s. 149-170). Bu çalışmaların en önemlilerinden biri Featherstone tarafından yazılan ve Yunanistan'ın 1990’larda yaşadığı hızlı Avrupalılaşma sürecine değinen “ Avrupalılaşma ve Merkez Çevre: 1990'larda Yunanistan Örneği” isimli çalışmadır. Bu çalışmanın konusu olan Yunanistan'daki azınlık haklarının Avrupalılaşması süreci de aynı teorik yaklaşımla, bir modernleşme süreci olarak açıklanabilir. Featherstone'a göre, Yunanistan'da ve Güney Avrupa'da modernleşme kavramı “Batı Avrupa normlarına ve uygulamalarına yaklaşmak" olarak değerlendirilmekteydi. Geçmişte "modernleşme" olarak adlandırılan "Batı Avrupa değerlerine yaklaşma süreci", bu değerlerin Avrupa Birliği üyeliği için ön şart haline gelmesinden sonra bu süreç Avrupalılaşma olarak adlandırılmaya başlandı (Featherstone, 1998, s. 2). Avrupalılaşma, yerel gündemi dönüştüren, yerel güçleri yeniden yapılandıran bir süreçtir. Yunanistan'daki siyasal süreç de Avrupalılaşma sayesinde Atina'nın kontrolünün ötesine taşınmıştır. Bir modernleşme süreci olarak Avrupalılaşma Yunanistan'ı daha açık, Avrupa'dan gelen talepler karşısında daha savunmasız, Avrupa'nın içine nüfuz ettiği bir ülke haline getirmiştir. Yine Featherstone'a göre, 1990'larda Yunan siyasal sisteminde yaşanan hiçbir gelişmeyi Avrupalılaşmadan bağımsız olarak açılklamak mümkün değildir. (Featherstone, 1998, s. 38). Yunanistan'da 1990'lardan beri azınlık haklarında yaşanan bazı olumlu düzenlemeleri de bu çerçevede değerlendirmek mümkündür.

Makalesinde özellikle Yunanistan Dış Politikasının Avrupalılaşma sürecine değinen Economides de Yunanistan'ın Avrupalılaşma sürecini bir modernleşme süreci olarak değerlendirmektedir. Economides'e göre Yunanistan'ın 1990'larda yaşadığı Avrupalılaşma süreci aynı zamanda bir "batılılaşma" ve "modernleşme" süreci olarak nitelendirilebilir (Economides, 2005, s. 475). Avrupa Topluluğu üyeliği sürecinde, Yunanistan için, modernleşme batılılaşma anlamına gelirken, batılılaşma ise Avrupalılaşma anlamına gelmekteydi (Economides, 2005, s. 476). Sonuç olarak bu tanımların neredeyse eş anlamlı olarak kullandığını ifade etmek yanlış olmayacaktır.

Ioakimidis Yunanistan'ın Avrupalılaşma süreciyle ilgili yapılmış en önemli çalışmalardan birine imza atmıştır. Yunanistan'ın Avrupalılaşma 
sürecine değinirken yeni bir sinıflandırma ortaya koyan Ioakimidis, Avrupalılaşma kavramını iki ayrı başlıkta incelemektedir: (a) Cevap Veren (Responsive) Avrupalılaşma ve (b) İstenilen-planlanmış (intended) Avrupalılaşma (Iokimidis, 2000, s. 74). Cevap Veren Avrupalılaşma (Responsive Europeanization) sürecinde ülkenin Avrupa normlarına ve dinamiklerine ulaşabilmesi için siyasi aktörler tarafından anlamlı bir çaba gösterilmemektedir. $\mathrm{Bu}$ tarz Avrupalılaşma süreci Avrupa bütünleşme sürecinin siyasi sistem üzerindeki baskıları sonucunda oluşmaktadır. $\mathrm{Bu}$ yüzden siyasi aktörler tarafından yürütülen bir değișim ve modernleşme süreci olarak nitelendirilemez. İstenilen- planlanmış (Intended Europeanization) Avrupalılaşma ise modernleşmeyi hedeflemektedir. Bu tip Avrupalılaşma sürecinde siyasi aktörler ülkelerini Avrupa normlarına, mantığına taşımak için büyük bir istek içerisindedirler. Sistemlerini reformlarla modernleştirmek, bir diğer tabirle, "Avrupalılaştırmak" en önemli amaçlarıdır. Avrupalılaşma ülkedeki siyasi elitler tarafından planlanarak uygulanan Avrupa modelinin kopyalanması olarak da açıklanabilir. Böylece, Avrupalılaşma süreci modernleşme adına ülkenin değişim programı ve siyasi reformlar için bir slogan haline gelmektedir (Ioakimidis, 2000, s. 75). Çalışmanın bundan sonraki kısmında değinileceği üzere, 1996 yılında iktidara gelen modernleşme yanlılarının nihai hedefi ülkeyi Avrupa'nın merkez ülkelerinden biri yapmaktır. $\mathrm{Bu}$ çerçevede ülkede hızlı bir reform süreci yaşanmış ve ülkenin Avrupa Birliği içindeki imajı ve tutumu gözden geçirilmiştir. Azınlık hakları konusunda atılan bazı olumlu adımlar da bu modernleşme süreci dâhilinde Avrupa normlarını ve değerlerini kopyalama çabası sonucu gerçekleşmiştir.

\section{Yunanistan'ın Avrupa Yolculuğu}

Avrupa Birliği'nde ufak bir çevre ülkesi olan Yunanistan'ın uyum süreci oldukça sancılı ve uzun olmuştur. Avrupa'nın etnik karışıklıklarının yoğun olarak yaşandığı bir bölgesinde konumlanan Yunanistan, kültürel, tarihsel ve dinsel olarak diğer üyelerden ayrılmaktaydı.

İkinci Dünya Savaşını takip eden Yunan İç Savaşı Döneminde, komünist güçlerin Batılı ülkelerin desteğiyle yenilmesi ile birlikte Batı bloğunun bir parçası olmuştur. Bu dönemden sonra yavaş seyreden bir modernleşme ve Avrupalılaşma çabası içine girmiştir. 1981'de Avrupa Ekonomik Topluluğu'na üye olan ülke, uzun süre birlik içinde bir "öteki” olarak konumlandırılmıştır. (Clogg, 1993). Katolik ve Protestan birlik üyelerinden Ortodoks kimliğiyle de ayrılan Yunanistan, Katolik - Protestan Avrupa'yı Helen Ortodoksluğunun tarihsel düşmanı olarak konumlandırmaktaydı. Yunan kilisesi de bu ayrımı gözler önüne sermek ve desteklemek için yoğun çaba sarf etmekteydi.

Yunan siyasi kültürü incelendiğinde Avrupalı ortaklarından çok farklı bir fotoğraf karşımıza çıkmaktadır. Siyasi kültürünün belirleyici faktörleri 'popülizm' ve 'kayırmacılık' olan Yunanistan bu özellikleriyle de Avrupalı ortaklarından hayli farklı konumdaydı. Yunanistan Avrupalı çoğu ortağının aksine "kurumlar" değil "liderler" ülkesidir. Bu liderlerin, keyfi, milliyetçi ve 
tutarsız uygulamaları ülkeyi Birlik içinde zor durumlara sokmuştur. Bütün bu uygulamaların sonucu olarak, Birlik üyeleri nezdinde Yunanistan'ın imajı çok olumsuz etkilenmiştir. Yunanistan'ın Avrupa Ekonomik Topluluğu üyeliği, 1967 - 1974 yılları arasında ülkeyi yöneten Yunan Cuntasının, 1974'te Türkiye'nin Kıbrıs'a müdahalesiyle devrilmesini takip eden dönemde gerçekleşmiştir. Türkiye'nin Kıbrıs'a asker çıkarması Yunanistan'ın tehdit algısını Sovyetler'den komşu Türkiye'ye yöneltmiştir. Kıbrıs konusunda Türkiye ile askeri bir çatışmaya giremeyecek olan Yunan Cuntası zorunlu olarak yönetimi eski politikacılara bırakmıştır.

Yunanistan önemli siyasi simalarından olan Konstantin Karamanlis sürgünde olduğu Paris'ten dönüp Yunanistan'ın başına geçmiștir. Türkiye'nin Kıbrıs'a müdahalesini engellemeyen NATO ve Amerika'ya güveni kalmayan Yunanistan, güvenlik kaygılarıyla yeni bir ortak arayıșına girmiștir. Bu bağlamda Avrupa ile entegrasyon Türkiye'ye karşı bir güvenlik garantisi olarak algılanmıştır.

1975 tarihinde Yunanistan Topluluğa tam üyelik başvurusunda bulunmuş, dış politikasının temellerini "Yunanistan Batıya aittir" şeklinde belirlemiştir. Ülke, Avrupa Topluluğu üyeliğiyle hem demokrasisini teminat altına alacak, hem de 2. Dünya Savaşı sonrasından beri süregelen Amerikan bağımlılığını azaltacaktı. Topluluk tarafından da Yunanistan'ın üyeliği siyasi bir karar olarak algılanmış ve Yunanistan demokrasisinin teminat olarak görülmüştür. Diğer yandan, Yunanistan'ın üyeliği Topluluk için ciddi riskler taşımaktaydı. Hem Türk-Yunan uyuşmazlığına taraf olmak, hem de ekonomik olarak Topluluğun çok gerisindeki bir ülkeyi kabul etmek bu risklerin en önemli olanlarıydı. Ayrıca, Topluluğun genişlemesi karar alma süreçlerini etkileyebilecek iç siyasi karışıklıklara sebep olabilirdi.

Karamanlis Avrupa'da var olan bu endișelerin kişisel çabalarıyla üstesinden gelmiştir. Ayrıca Avrupalı liderlerde var olan "Philhellenism Yunan sempatisi” üyeliğin yolunu açan faktörlerden biri olmuştur. Antik Yunan uygarlıklarına duyulan bu hayranlığın temelinde Antik Yunan'ın demokrasinin doğum yeri olması gelmektedir. Avrupalı liderlere göre, maliyeti ne olursa olsun Yunan demokrasisinin korunması için Avrupa ailesinde ona bir yer vermek gerekmektedir. Bütün ekonomik ve siyasi sorunlarına rağmen, Yunanistan 1981 yılında Avrupa Topluluğu'nun onuncu üyesi olarak kabul edilmiştir.

Üyelik antlaşmasının imzalanmasından dokuz ay sonra, seçim kampanyasında ülkenin Avrupa Topluluğu üyeliğine karşı çıkarak oy toplamayı başaran Andreas Papandreou başkanlığındaki PASOK iktidara geldi. İktidarının ilk döneminde sempatizanlarını kamu görevlerine atayan, sosyal politikalarını finanse etmek için devaml borçlanan PASOK, giderek artan bütçe açığına rağmen 1985 seçimlerini kazanmayı başardı (Lyrintzis, 1993, s. 27). Bu dönemde Avrupa'ya karşı daha ılımlı bir siyaset yürüten Papandreou'nun bu açılımının temelinde ekonomik kaygılar bulunmaktaydı. Yine bu dönemde, seçim öncesi vaatlerinin aksine, ilk kez Yunanistan'ın Avrupa Topluluğu'ndan çıkmayacağını duyurdu. Yunanistan için Avrupa ile bütünleşme daha fazla 
ekonomik kaynak anlamına gelmekteydi. Papandreou yönetiminde Yunanistan, Topluluktaki fikir birliğini bozan, keyfi vetolar kullanarak karar alma mekanizmalarını sekteye uğratan, buna karşılık Topluluktan gelen finansal destekle ekonomisini ayakta tutan bir üye profili çizmiştir. Avrupa içinde Yunanistan'a duyulan sempatide ciddi bir azalma olmuş, öte yandan Yunan halkında Avrupa sempatisi giderek artmıştır. Yunan halkının "Yunanistan Avrupa Topluluğu üyeliğinden fayda görmüştür" düşüncesi 1985 yılında \% 42 iken bu oran 1986 yılında \%60'a yükselmiștir. (Avrupa Komisyonu, t.y.).

1990’ların ortasına kadar Avrupa karar alma mekanizmalarını sık sık keyfi olarak sekteye uğratan Yunanistan'da milliyetçilik dominant ideoloji olarak konumunu korumuş ve iç siyasette daha fazla destek kazanmak için uyguladığı politikalarla Birlik içinde "Avrupa'nın Kara Koyunu” olarak adlandırılmaya bașlanmıștır (Economides, 2005, s. 471-491). Bu döneme kadar Birliğe herhangi bir somut katkısı olmamıştır. 1996'da sağlığı bozulan ve sonrasında hayatını kaybeden Andreas Papandreou'nun yerini modernleşme ve Avrupalılaşma taraftarı Kostas Simitis almıştır. Böylece Karamanlis'in Cumhurbaşkanlığı'nın sona ermesi ve Papandreou'nun siyaset sahnesinden çekilmesiyle Yunanistan siyasetinde "dinozorlar" dönemi sona ermiştir (Clogg, 2002). Yönetime gelen bu modernleşme yanlıları Yunanistan'ı Avrupa'nın merkez ülkesi haline getirmeyi ve Avrupa Birliği içinde bir Balkan ülkesi olmaktansa, Balkanlardaki Avrupalı ülke olmayı hedeflemişlerdir. Ioakimidis'e göre Yunanistan Avrupalı olmak yerine uzun yıllar Avrupa Topluluğu içinde bir Balkan ülkesi olarak hareket etmiştir (Ioakimidis, 2001). Simitis için modernleşme ve Avrupalılaşma eş anlamlı iki kelimedir ve Yunan siyaseti bu doğrultuda evrilmelidir. Bu gelişimi sağlamak ekonomik, sosyal ve siyasi bazı reformların hayata geçirilmesi ile mümkün olacaktır.

Simitis Hükümeti'nin hedefleri oldukça açıktı: Avrupa Para Birliği'nin bir parçası olabilmek için gereken Maastricht kriterlerinin karşılanması, TürkYunan yakınlaşmasının sağlanması, Türkiye ile var olan sorunların Avrupa Birliği şemsiyesi altına taşınması en öncelikli konulardı. Yunanistan siyasetindeki geleneğin aksine Simitis karizmatik bir lider değildi. Geçmişinde herhangi bir yolsuzluk veya usulsüzlük yoktu. Parti içindeki geleneksel kanatla mücadele içindeydi ve hedeflerini gerçekleştirmek için hem onları tasfiye etmesi, hem de Yunanistan'ın uluslararası imajını düzeltmesi gerekiyordu.

Türkiye ile yakınlaşma hedefini gerçekleştirebilmesi için hem parti içindeki geleneksel kanatla mücadele etmesi hem de halkın desteğini kazanması şarttı. Yönetime geldikten sonra Türkiye ile Yunanistan arasında kontrolü dışında gelişen bazı hadiseleri de kullanarak milliyetçi geleneksel kanadı partiden tasfiye etmeyi başarmıştır. Terör örgütü PKK lideri Abdullah Öcalan'ın Kenya'daki Yunan büyükelçiliğinde yakalanması hem Yunanistan'ın uluslararası alanda imajını sarsmış hem de Türkiye'nin büyük tepkisine neden olmuştur. İşte bu olay tasfiye hareketinin gerçekleşmesi için Simitis adına bir fırsata dönüşmüştür. Halkın desteğini alması ancak 1999 yılında Türkiye'de ve Atina'da ardı ardına gerçekleşen yıkıcı deprem felaketlerinin iki ülke halkı arasında yarattığı sempati ve empati vasıtasıyla gerçekleşmiştir. Karşılıklı 
yardımlaşma ve acıların karşılıklı olarak hissedilip paylaşılması iki ülke ilişkilerinin gelişmesi için bir vasıta haline gelmiş oldu. Bu dönemde ilişkilerin gelişmesi "deprem diplomasisi" olarak adlandırılmaktadır. 3 Yöneticiler tarafından başlatılmış olan yakınlaşma dönemi böylece halklar arasında karşılı̆̆ını bulmuş oldu.

Türkiye'nin Avrupa Birliği üyeliğine geleneksel olarak veto koyan Yunanistan bu tutumundan vazgeçerek Türkiye'nin $\mathrm{AB}$ adaylığının önünü açarak üyeliğini desteklemeye bașlamıștır. Simitis'e göre Avrupa Birliği'ne yakın bir Türkiye Yunanistan'ın milli çıkarları için daha yararlı olacaktır. Böylece müzakere sürecinde sorunlar masaya yatırılacak ve Türk- Yunan uyuşmazlığı da Avrupalılaşacaktır. Avrupalılaşmasının önünde duran en büyük engeller ise ülke içindeki geleneksel odaklar olmuştur. Modernistler, özellikle Yunan Kilisesi'nin büyük muhalefetiyle karşılaşmışlardır. Yunan Kilisesi bağımsızlıktan bu yana Yunan milliyetçiliğinin kalesi olmuş ve KatolikProtestan Avrupa ile entegrasyonun, modernleşmenin ve Batılılaşmanın karşısında olmuştur. Yunanistan komşularıyla ilişkilerinde olumlu gelişmeler sağlamış, Avrupa Birliği içinde daha uyumlu bir ortak haline gelmiş, Avrupa genişlemesini destekleyerek Güney Kıbrıs'ın Avrupa Birliği üyeliğini garantilemiştir.

Simitis'ten sonra gelen hükümetler de Avrupalılaşma konusunda kendisini takip etmiş, Türk - Yunan ilişkilerindeki yakınlaşma ortamını devam ettirmişlerdir. Yunanistan,2008'den beri büyük bir ekonomik krizle boğuşmaktadır ve kriz nedeniyle Avrupa ile ilişkilerinde ekonomik boyut öne çıkmıştır. Bu dönemde Avrupa'dan mali destek alan Yunanistan ekonomisi tamamen dışa bağımlı olmuş, mali yardımlar karşısında yapılması istenen bazı reformlara Yunan halkından büyük tepkiler gelmiş ve Avrupa'nın merkez ülkelerine karşı Yunan halkında büyük bir tepki oluşmuştur. Aynı zamanda kriz ülkedeki yabancı düşmanlığını da körüklemiş, ülkede yaşayan göçmenler ve azınlık mensupları aşırı sağ partilerin hedefi haline gelmiştir.

\section{Azınlık Hakları ve Avrupa Birliği}

Azınlık haklarını düzenlemeye yönelik faaliyetlere uluslararası ilginin artması, genel olarak, devletlerarası kriz ve çatışmaların arttığı, sistemi etkileyen büyük sınır değişikliklerinin veya sistemlerin dönüşümlerinin yaşandığı dönemlere denk gelir. Bu açıdan 1815, 1878, 1919, 1945 ve 1990 kritik tarihler olarak değerlendirilebilir (Aykoç, 2009, s. 55). 1990’lardan sonra Avrupa'da azınlık haklarına yönelen ilginin sebebi Doğu bloğunun çöküşüyle açıklanabilir. 1990'ların başından beri Avrupa Konseyi, Avrupa İnsan hakları

\footnotetext{
3 “Deprem Diplomasisi” terimi için bakınız: Siegl, E. (2002). Greek-Turkish relations- continutiy or change? Perspectives: Central European Review of International Affairs (18), s. 40-52; Keridis, D. (2006). Earthquakes, diplomacy and new thinking in foreign policy. The Fletcher Forum of World Affair's (30), s. 207; Rumelili, B. (2004, Ocak). The European Union's impact on the Greek-Turkish conflict: A review of the literature. Working Papers Series in EU Border Conflicts Studies (6).
} 
Mahkemesi ve Avrupa Birliği, insan hakları çerçevesinde azınlık haklarının geliştirilmesinde önemli rol oynamışlardır.

Özellikle Doğu Avrupa ülkelerdeki komünist rejimlerin yıkılması ve buna bağlı olarak bölgede ortaya çıkan etnik problemler Avrupa Birliği'ni konuya daha hassas yaklaşmaya itmiştir. Sovyetler Birliği, Çekoslovakya, ve Yugoslavya'nın parçalanması sonucunda içlerinde azınlıklar barındıran 28 yeni devlet ortaya çıkmıştır. Bu ülkelerin $\mathrm{AB}$ ile entegrasyon çabasına girmesiyle beraber AB'nin, bu etnik problemlerin bölgedeki ve birlik içindeki istikrarı bozabileceği varsayımıyla, azınlık haklarına daha fazla vurgu yapmasına sebep olmuştur. İnsan hakları, eşitlik, adalet gibi değerlere yapılan vurgu da eş zamanlı olarak artmıştır. Bu süreç aday ülkeleri etkilediği kadar birlik içindeki ülkelerin azınlık politikalarını da gözden geçirmelerine sebep olmuştur. Yine aynı dönemde, Birliğe üye olmak isteyen ülkelerin önüne "azınlık haklarını güvence altına alarak barışçıl ve adaletli bir biçimde çözmelerini ve belli bir siyasal/toplumsal/ekonomik gelişme aşamasına gelmeleri" şart koşulmuştur (Aykoç, 2009, s. 133). Buradaki temel kaygı bölgedeki istikrarsızlığın AB içine transferini engellemektir.

Avrupa değerleri olarak karşımıza çıkan, hukukun üstünlüğü, insan haklarına saygı ve eşitlik üye ülkeler tarafından iyi bir şekilde özümsenip, tatbik edilmeliydi. Aday ülkelerinin önüne konulan bu değerler üyeler tarafından tatbik edilip, adaylar tarafından model alınacak düzeye gelmeliydi. Yine aynı dönemde Avrupalılık vurgusu da daha yoğun bir şekilde gündeme getirilmiştir. İnsan haklarına saygılı, Avrupa değerlerini özümsemiş bir kimlik inşa ederek Avrupa bütünleşmesini pekiştirmeyi hedeflemektedir.

Komisyon'un 1999'da yayımladığı "aday ülkeler için ilerleme raporunda" üyelik için konulan siyasi kritere göre "Avrupa Birliği’ne aday ülkelerin, üye olabilmek için demokrasiyi koruyacak kurumların istikrarını sağlamaları, insan haklarına ve azınlıkların korunmasına saygı göstermeleri ve hukukun üstünlügünü tesis etmeleri gerekmektedir". Ayrıca Amsterdam Anlaşmasının 6. Maddesine göre, "Avrupa Birliği; özgürlük, demokrasi, insan haklarına ve temel haklara saygı ve hukukun üstünlügü ilkeleri üzerine kurulmuştur" (Schwellnus, 2001). Avrupa Birliği Anayasa taslağının I-2. Maddesine göre; "Birlik, insan onuruna saygı, özgürlük, demokrasi, eşitlik, hukuk devleti ve azınlıklara mensup kişilerin haklarını da içeren insan haklarına saygı değerleri üzerine kurulmuştur. Bu değerler, çoğulcu, ayrım gözetmeyen, hoşgörülü, adil, dayanışmacı ve kadınlar ile erkekler arasında eşitliğin hüküm sürdüğü bir toplumda, Üye Devletlerin hepsi için ortaktır" (Avrupa Birliği Anayasası, t.y). Böylece $A B$ anayasası hazırlanırken azınlıklara saygı vurgulanmış ve $A B$ 'nin üzerine kurulduğu değerleri arasında yerini almıştır.

Avrupa Birliği'nin azınlıklar konusunda aday ülkelere koymuş olduğu kriterlerin varlığına ve azınlık haklarına saygı ve eşitlik kavramlarını Avrupa değerleri içinde vurgulamasına rağmen üye ülkeler konusunda somut bir iyileşme gösterilememiş olduğu da bir gerçektir. Buna rağmen Avrupa kurumlarının ve AB'nin etkisiyle ve de dünyada azınlık haklarına yapılan vurgunun yoğun bir şekilde gündemde olması sebebiyle üye ülkelerdeki haksız 
uygulamalarda bazı değişiklikler gözlenmektedir. Yunanistan'ın azınlık haklarında iyileştirmeye yönelik faaliyetleri de bu döneme denk gelmektedir.

\section{Yunanistan'ın Avrupalılaşması ve Azınlık Haklarına Yansıması}

1990’larda uluslararası alanda azınlıklara yapılan vurgunun artmasıyla Avrupa Konseyi ve Avrupa Birliği de azınlık haklarının iyileştirilmesini bir siyasi kriter olarak ortaya koymuşlardır. Avrupa Konseyi azınlıkların korunmasına özen göstererek, bu konuda raporlar yayımlamış, $A B$ ise azınlıklara saygı ve azınlıkların korunması hususunu Avrupa değerleri içine almıştır. Avrupa Birliği bütünleșmeye giden yolun önemli bir unsuru olarak kültürel ve dilsel farklılıkların korunmasını görmüş ve bu yaklaşım azınlık kültürlerinin korunması konusundaki çabaların hızlanmasına neden olmuştur.

Bu dönemde, sadece uluslararası örgütler değil, sivil toplum kuruluşları da azınlık konularında faaliyetlerini arttırmıştır. Sivil toplum kuruluşları bu kurumların azınlık sorunlarına eğilmeleri ve bu sorunlara dikkat çekme konusunda etkin olmuştur. Batı Trakya konusunun Avrupa'nın gündemine taşınmasında, azınlık konusuna artan ilginin yanı sıra konuyu uluslararası platforma taşıma gayreti içindeki azınlık mensupları ve örgütlerinin etkisi de belirleyici olmuştur. Özellikle, (Federal) Almanya'da yaşayan ve örgütlenen Batı Trakyalılar, 1980'lerin son yıllarından itibaren düzenledikleri yürüyüșler ve bu yürüyüşlerde dağıttıkları bildirilerle, Avrupalıların dikkatini Batı Trakya'da yaşanan hak ihlallerine çekme konusunda büyük çaba sarf etmişlerdir (Batı Trakya'nın Sesi, 1988, s. 26). Azınlığın yaşadığı ayrımcı uygulamalar ve azınlığın başlıca sorunları; etnik kimliğin reddi, din ve vicdan hürriyeti konusundaki sorunlar, vatandaşlıktan çlkarılma, vakıflar sorunu, örgütlenmenin engellenmesi, taşınmaz mal alıp satmanın engellenmesi, kamu görevlerinde istihdam edilememe, siyasi katılım ve temsil sorunu, eğitim ve öğretim konusundaki sorunlardır. Üzerlerinde artan baskının sonucu olarak 1980'lerde hızla hak arayıșına giren azınlık mensupları Yunan parlamentosuna bağımsız listelerden temsilci göndermeyi bașarmıștır. Maalesef, 1990’ların ilk yıllarında değiştirilen seçim sistemi ve konulan \% 3 barajı azınlığın meclise bağımsız aday göndermesinin önünü kapamıştır. \% 3 barajı aşmak için 200.000 oy gerekir ve bu rakam azınlığın nüfusunun üstündedir. Bu durumda, azınlık mensuplarının parlamentoya girişi siyasi partilerin takdir ve değerlendirmesine bırakılmaktadır. 2014 yılında BM İnsan Hakları Konseyi Oturumunda seçim barajı sorununu dile getiren Avrupa Batı Trakya Türk Federasyonu yetkilileri “Avrupa Birliği alanında azınlıkların korunmasının aday ülkeler için katılım öncesi şartlardan biri olduğunu ancak bu şartın maalesef Yunanistan dâhil eski AB üyeleri için geçerli olmadığını" ifade etmiş, böylelikle hem Yunanistan'ı hem de Avrupa Birliği'nin tutumunu eleştirmişlerdir. (ABTTF, 2014)

Azınlığın en temel sorunlarının başında etnik kimliğin reddi ve müftülük meseleleri gelmektedir. 1984'de Mahkeme kararıla " Türk" kelimesinin kullanılması yasaklanmıştır. İsminde "Türk" kelimesi geçen derneklerin 
tabelaları sökülmüştür. Yunanistan, ülkede Türk azınlık olmadığını, Lozan Antlaşmasına uygun olarak "Müslüman" azınlığın var olduğunu vurgulamaktadır. Müslüman kimliğinin öne çıkarılmasına rağmen Batı Trakya azınlık mensuplarının dini özgürlükler konusunda da mağduriyetleri halen sürmektedir. Azınlığın dini liderlerini seçmesi engellenmiş, seçilen müftülere görev vermeyip devlet müftü atamıştır. Bu durumda Gümülcine ve İskeçe'de "seçilmiş" ve "atanmış" müftüler görev yapmaktadır. Yunanistan'ın bu konudaki iddiası müftülerin aynı zamanda devletin yetkisine giren işlerden de sorumlu olmalarıdır. Yunan devleti tarafından atanmış olan, fakat azınlık tarafından benimsenmeyen müftüler, evlenme, miras, boşanma gibi işlerle ilgili yetkiyi ellerinde bulundurmaktadırlar. Din ve vicdan özgürlüğüne aykırı olan bu uygulama halen devam etmektedir ve atanan müftüler azınlık tarafından kabul görmemektedir. Gümülcine Seçilmiş Müftüsü İbrahim Şerif, 1990’lı yılların başında ceza kanununun 175. maddesini ihlal ettiği iddiasıyla yargılanmış ve mahkeme tarafından 8 ay hapis cezasına çarptırılmışt (Gündem, 2017). Şerif, statüsünün tanınmaması konusunu Avrupa İnsan Hakları Mahkemesi'ne taşımış, mahkeme 1999'da verdiği karar sonucunda Yunanistan'ı 2.7 milyon drahmi tazminat ödemeye mahkum etmiştir (Memişoğlu, 2007, s. 7). 1997 yılında din ve özgürlükler konulu AGİT raporunun Yunanistan ile ilgili bölümünde Yunanistan'da uygulamaya bakıldığında din özgürlügünün bulunmadığı ifade edilmiştir. Yunanistan'daki Müslüman azınlığın çoğunluğu tarafından seçilmiş olan müftülere "makamı taklit" iddialarıyla uygulanan hukuki tedbirlere de raporda yer verilmektedir (Nurioğlu, 1997, s. 4). Tüm bu raporlara ve uluslararası mahkeme kararlarına rağmen, Rodop Savcılığı Mart 2018 tarihinde, Gümülcine seçilmiş müftüsü İbrahim Şerif'e "düzenlenen bir toplu sünnet etkinliğine katılarak resmi makamı gasp ettiği" gerekçesiyle hakkında dava açılmasına karar vermiştir (Anadolu Ajansı, 2018).

Eğitim konusu da azınlığın en büyük sorunlarından birini teşkil etmektedir. Türkiye'den alınan diplomaların denkliğinin sayılmaması, azınlık okullarının yetersizliği ve geri bırakılması, çift dilli eğitimdeki sorunlar bașı çekmektedir. Uzunca bir süre eğitimde eşit firsat sahibi olmayan Bat Trakyalı gençler eğitim alabilmek için Türkiye'ye gitmiş ve birçoğu geri dönmemiştir. Türkiye'de okuyan öğrencilerden vatandaşlıktan çıkarılanlar olduğu gibi, diplomalarına denklik alamama gibi sorunlar yüzünden de Türkiye'ye yerleşmeyi tercih edenler olmuştur. Eğitim sorunları göçün en önemli sebeplerinden birini oluşturmaktadır.

Vatandaşlıktan atılma sorununa geldiğimizde bu problem sadece Türkiye'de eğitim gören gençleri mağdur eden bir sorun değildir. Yunan Vatandaşlık yasasının 19. Maddesinin keyfi bir şekilde uygulanması sonucu 60.000 civarında Batı Trakyalı vatandaşlığını kaybetmiş, vatansız olarak hayatlarına en temel haklarından yoksun bir şekilde devam etmek zorunda kalmışlardır. Bu ayrımcı maddeye göre, Yunan ırkından olmayan bir Yunan vatandaşı ülkeyi dönmemek üzere terk ederse vatandaşlıktan atılabiliyordu. 19. Madde mağdurlarının birçoğu Türkiye ve Avrupa ülkelerinde ikamet eden Yunan vatandaşları olmakla beraber, Yunanistan sınırlarında yaşamaya devam 
eden hatta Yunan ordusunda askerlik görevini yaparken vatandaşlıktan çıkarılan insanlar da bulunmaktadır. Buradan da anlaşılacağı gibi 19. Madde azınlık üzerinde oldukça keyfi bir şekilde uygulanmış ve binlerce insan mağdur edilmiş, vatansız bırakılmıştır (Hayrullah, Hüseyinoğlu ve Kabza, 2014).

Bütün bu sorunların varlığına rağmen, Yunanistan'daki azınlık haklarında, Avrupa kurumlarının azınlık haklarına artan ilgisine paralel olarak gelişen olumlu düzenlemeler de olmuştur. İlk olarak 1990-93 yılları arasında Başbakanlık yapan Mitsotakis bölgeyi ziyaret etmiş, azınlığın içinde bulunduğu olumsuz şartları önceki hükümetlerin uygulamalarına bağlamış ve "yasalar önünde eşit vatandaşlık" ilkesini benimsediklerini belirtmiştir. Bu dönemle birlikte Yunanistan'ın geleneksel azınlık politikasından bir kayma gözlemlemek mümkündür. Buna rağmen, 1996 yılında Avrupa Birliği Komisyonu'nca hazırlana raporda azınlıktan "Türk azınlık" olarak bahsedilmesi Yunan gazetelerinde infial yaratmış ve kınanmıștır (Gündem, 1996a, s. 6). Bu dönemde Batı Trakya Türkleri'nin sorunları Avrupa Güvenlik ve İşbirliği Teşkilatı toplantılarında da dile getirilmiştir. Bu toplantılarda Müftülük konusu, etnik kimliğin reddi, eşit iş imkânları ve eğitim fırsatlarına erişimin engellenmesi ve Yunan vatandaşlık yasasının 19. Maddesi nedeniyle yaşanan mağduriyetlere vurgu yapılmaktaydı (Gündem, 1996b, s. 1). AGİT'in devletler üzerinde yaptırım gücü olmamasına rağmen, bu hazırlanan raporlarla, azınlık ile ilgili mağduriyetlerin Avrupa gündemine taşınmasında büyük rol oynamıştır. Bu dönemde azınlık mensuplarının Avrupa Konseyi Parlamenterler Meclisi'ne yaptıkları ziyaretler de sonuç vermeye başlamıştır. AKPM Hukuk İşleri Komisyonu toplantısında bir açılklama yapan Sosyalist Parlamenter Lydie Err Yunanistan'ın sistemli bir biçimde Türk azınlık mensuplarını Yunanistan vatandaşlığından çıkarmak istediğini ve azınlığın ibadet özgürlügünün engellendiğini belirterek ve bu sorunlarla ilgili olarak İnsan Hakları Alt Komisyonu'nda gerekli çalışmaların yapılmasını istemiştir (Gündem, 1996c, s. 3). 1996 yılı Eylül ayında Avrupa Parlamentosu'nca yayınlanan insan hakları raporunda Yunanistan eleştirildi ve buna delil olarak da vicdani inançlardan dolayı insanların hapsedilmeleri, azınlıklık haklarının, düşünce özgürlüğünün, dini özgürlüklerin kısıtlanması gösterilmiştir (Gündem, 1997a, s. 7).

1997 yılında Lüksemburglu parlamenterin başını çektiği 10 Avrupalı parlamenterin imzasıyla ortak olarak sunulan karar tasarısında da Atina'ya, azınlığa karşı yapılan haksız muameleye son vermesi çağrısı yapılmıştır. Tasarıda, Yunan vatandaşı olan Türk azınlığa karşı azınlık haklarının ihlal edildiği, Yunan makamlarınca baskıya ve ayrıma tabii tutuldukları, taşınmaz mal alımında, eğitim, sağlık gibi hizmetlerde haksızlığa uğratıldığı belirtilmiștir (Gündem, 1997b, s. 1, 48). 1997 yılı Avrupa'da "Irkçılıkla Mücadele Yılı" olarak ilan edilmiştir. Bu bağlamda, Avrupa'da yaşayan Batı Trakya Türkleri, Avrupa Parlamenterleriyle yaptıkları görüşmelerle konuya uluslararası ilgili çekme konusunda önemli adımlar atmışlardır (Gündem, 1997c, s. 7).

Avrupa'nın ilgisi ve azınlığın konuyu Avrupalılaștırma girişimlerine paralel olarak, Yunanistan'da azınlık haklarıyla ilgili yaşanan olumlu değişiklikler 1996'da göreve gelen Simitis hükümetiyle beraber somut bir hal 
almaya başlamıştır. Yeni hükümet hızlı bir Avrupalılaşma çabasına girmiş ve Avrupa'da insan haklarına artan ilginin de farkında olarak bazı olumlu düzenlemeleri hayata geçirmiştir. 1996 yılında azınlığa cami ve evlerinin tamir ettirme ve ev yaptırma izni verilmeye başlanmış, traktör ve araba ehliyeti, banka kredisi almanın yolu açılmıştır. Köylerdeki alt yapı çalışmaları hız kazanmış, elektrik, su ve asfaltlama konularındaki sorunlar çözülmüştür (İsmail, 2012, s. 85-87). Yine 1996'da, Batı Trakya Türk öğrencilerini Yunanistan'daki üniversitelerde okumasını sağlayan 0,05'lik kontenjan açıklanmış ve azınlık mensubu öğrencilerinin Yunanistan'ın büyük şehirlerinde okuyabilmesinin yolu açılmıştır. Bu değişiklikten önce, azınlık öğrencileri çoğunlukla Türk üniversitelerine gitmekte ve Türkiye'ye yerleşmekteydi. Bunun nedeni ise ilkokuldan itibaren azınlık okullarında temel dersleri bile Türkçe okuyan öğrencilerin Yunanca dilinde yapılan sınavlarda başarılı olma ihtimalinin çok düşük olmasaydı. Eğitimde adaletsizlik ve ayrımcllık göç kalemlerinin en önemlilerinin başında gelmekteydi. Ayrıca, Yunanistan'a geri dönmeyi tercih eden Batı Trakyalılar ise denklik belgesi alamamakta ve mesleklerini icra etmekte önlerine güçlük çıkarılmaktaydı. Diploma denkliği alamayan bir grup öğrenci 1988 yılında açlık grevine başladılar (Yankı, 1988, s. 1). Bu olaydan sonra açlık grevi yapan gençlerden ikisinin diplomaları tasdik edilmiştir (Batı Trakya Türkleri Dayanışma Derneği Bursa Şubesi, 2009). Eğitim konusunda diğer bir önemli gelişme ise Avrupa Birliği fonlarıyla hayata geçirilen "Müslüman Çocukların Eğitiminde Reform Projesi"dir. Bu çalışma azınlık eğitiminin kalitesini arttırmayı ve iki dile de hakim bireyler yaratmaktır. Atina Üniversitesi'nden bir ekip tarafından yürütülen proje farklı disiplinlerden uzmanların desteğiyle hem kitapların hem de azınlık eğitiminin düzeltilmesini amaçlamaktadır. Bu projenin devamında yetişkenler için de toplum merkezleri açılmış annelerin de Yunanca öğrenmesi yolunda adımlar atılmıştır (AB Vizyonu, t.y.). Ayrica yine bu dönemde, kamu görevlerinde sadece Hristiyanların çalışabilmesi hükmü gelişen azınlık hakları doğrultusunda kaldırılmış, kağıt üstünde de olsa azınlık mensuplarına orduda subay olarak görev yapmanın da yolu açılmıştır.

1998'de ise Avrupa kurumlarının yoğun baskısı sonucu, Yunanistan Vatandaşlık Yasasının 19. maddesi bir yasayla iptal edildi. Bu maddeye göre "Yunan ırkından olmayan bir Yunan vatandaşı, Yunanistan'ı dönmemek üzere terk ederse vatandaşlıktan atılıyordu." Bu keyfi uygulama yüzünden Yunan devlet kayıtlarına göre 46.000 civarı azınlık mensubu vatandaşlı̆̆ını kaybetmiştir. Bu yasa yüzünden vatandaşlığını kaybeden yaklaşık 60.000 kişi olduğu düşünülmektedir (Batı Trakya Online, t.y.). Bu maddeden mağdur olan Batı Trakyalılara vatandaşlık hakları geriye dönük olarak iade mağduriyeti halen devam etmektedir.

Yine bu dönemde AB'nin tarım sübvansiyonlarından Batı Trakya Türk çiftçisi yararlanmaya başladı. Ayrıca son yıllarda Yunanistan ile Türkiye ilişkilerinin yeniden yumuşak bir döneme girmesi ve iki ülke arasındaki ticaret hacminin sürekli büyümesinden Batı Trakya Türk azınlığı da istifade etti. Özellikle Türkiye'den bazı malların Batı Trakya Türkleri vasıtasıyla Yunanistan 
pazarına girmesi sağlandı (İsmail, 2012, s. 86). Yunanistan, 1996'da, 30 yıl gecikmeli olarak, BM Kişisel ve Siyasal Haklar Uluslararası Sözleşmesini (International Covenant on Civil and Political Rights, kısaca ICCPR) imzalamıștır. Yunanistan ayrıca 1997 yılında Avrupa Konseyi'nin Milli Azınlıkların Korunmasına İliş̧in Çerçeve Sözleşmesini imzalamış, sözleşme Yunan Meclisi'nde halen onaylanmamıştır. Bu sözleşmeyi hayata geçirmesi durumunda kendi sınırları içinde yaşayan etnik azınlıkların varlığını tanımak zorunda kalacağı için süreci geciktirmektedir (Avrupa Konseyi, t.y.).

Avrupalılaşma etkisinin görünür olduğu bir diğer konu ise 1990’larda yürürlüğe konan bölgesel yönetim reformlarıdır. Bölgesel kalkınma konusunda önemli adımlar atılmış, ülke 13 yönetim bölgesine ayrılmıştır. Doğu Makedonya - Trakya Bölgesi de bu bölgelerden biri olmuş ve bu gelişme azınlık mensuplarının yerel yönetimlerde daha fazla söz sahibi olmasına sebep olmuştur. Triandfyllidou ve Anagnostou'nun verilerine göre, Doğu Makedonya - Trakya Bölgesi, 1989-93, 1994-99, 2000-2006 dönemlerinde bölgesel kalkınma fonlarından 13 bölge içinde en yüksek destek alan 3. bölge olmuştur (Anagnostou ve Triandafyllidou, 2007, s. 6). Bahsi geçen rapora göre, bu reformlar azınlık mensuplarının kendilerini eşit vatandaş olarak algılamalarına katkıda bulunmuştur. Buna rağmen, yine aynı rapora göre, azınlık mensupları en az Yunanistan devletine güvenmektedirler. Azınlık mensuplarıyla yapılan görüşmeler sonucunda edinilen bulgular, Batı Trakya'da yaşayan TürkMüslüman azınlığın garantör olarak Türkiye'yi gördüklerini, Türkiye'den sonra ikinci sırada Avrupa Birliği'ne güvendiklerini göstermektedir (Anagnostou ve Triandafyllidou, 2007). İstanbul Üniversitesi'nde yapılan bir Yüksek Lisans çalışmasında, Batı Trakya Türk-Müslüman Azınlığına mensup kişilere "Azınlığın mevcut sorunları ileride kim tarafından çözümlenebilir?" sorusu yöneltilmiştir. Sonuçlar bir hayli dikkat çekicidir. Azınlık mensuplarının \% 42'si sorunların kendi çabalarıyla çözüleceğine, \% 38'i Avrupa Birliği vasıtasıyla, \%10’u Türkiye vasıtasıyla, \% 7'si Yunanlı politikacılar sayesinde çözüme kavuşabileceğine inanmaktadır (Çelikmen, 2010, s. 123). İki araştırmada ortak olan bulgu azınlığın sorunların çözümünde Yunanistan'a güvenmedikleridir. Bu çalışmanın odağı olan Avrupa kurumları ise, azınlık nezdinde sorunların çözülmesi noktasında önemli aktörlerdir. Yunanistan'ın Avrupalılaşma süreciyle paralel seyreden bahsi geçen iyileştirmeler bu algının gelişmesinde büyük rol oynamiştır.

1990’ların ikinci yarısından itibaren meydana gelen olumlu gelişmelere rağmen 1999 yılındaki AGİT raporunda "Yunanistan sınırları içinde ulusal azınlık yaşadığını kabul etmeyen tek Avrupa ülkesidir" denmekteydi (Nurioğlu, 1999, s. 4). 23 Temmuz 1999 tarihinde Avrupa Konseyi bünyesindeki Ulusal Azınlıkları Koruma Girișimi dâhilinde Yunan Parlamento Başkanı ve Parti Başkanlarına Türk ve Makedon azınlıkların tanınması yönünde çağrı yapılmıştır. Bunun sonrasında 29 Temmuz tarihli Klik dergisinde dönemin Dış İşleri Bakanı Georgios Papandreou “... Batı Trakya'da Türk kökenli Müslümanların olduğundan kimse şüphe etmiyor.. Şu anki ulusal sınırlardan şüphe edilmediği sürece, kişilerin kendini Müslüman veya Türk veya da Bulgar 
veya Pomak olarak tanımlamaları benim umurumda değil..” demiştir. Burada Avrupa kurumlarının özellikle 1990’ların ikinci yarısından itibaren konuya göstermiş oldukları ilginin Yunan siyasetçileri üzerinde yarattığı baskı ve etkiyi net olarak görebilmek mümkündür. Aynı yıl Avrupa Konseyi raportörleri Batı Trakya'yı ziyaret etmiş, hem halk hem de seçilmiş müftülerle karşılıklı görüşmeler yapmışlardır (Gündem, 1999, s. 5). 2000 yılında Avrupa Konseyi'nin bir kurumu olan Irkçılık ve Hoşgörüsüzlüğe karşı Avrupa Komisyonu'nun (ECRI) yayımlanan Yunanistan raporunda da, Türk Kimliği'nin inkârı, müftülük, vakıflar, eğitim ve 19. Madde mağdurlarının sorunları konularına yer verilmiştir. Söz konusu sorunların ivedilikle çözülmesi için Yunanistan'a tavsiye de bulunan Komisyon, azınlığın Lozan Antlaşması'ndan doğan haklarına da vurgu yapmıştır (Gündem, 2000, s. 5).

\section{Sonuç}

Yunanistan'ın Avrupalılaşma süreci ülkede azınlık haklarında yapılan bazı değişiklikleri anlamak adına çok önemlidir. Yunanistan, 1981 yılında Avrupa Ekonomik Topluluğu'na üye olduğunda Topluluk, günümüzdeki siyasi yapısından farklı olarak, üye devletlerarasında ekonomi politikalarının yaklaştırılmaları yoluyla bir ortak pazarın kurulmasını hedefleyen bir yapıya sahipti. Topluluğun o dönemki yapısı göz önünde bulundurulduğunda Yunanistan'ın üyeliğinin önüne azınlık haklarında iyileştirmeye gidilmesi gibi bir siyasi şart konulmamıştır. Bu dönemde üyelik için şart koşulan siyasi kriterlerin varlığından söz etmek bir hayli güçtür. 1990'larla beraber Birliğin siyasi kimliğinin ön plana çıkması ve Birlik dâhilinde insan haklarına yapılan vurgunun artması ile Avrupa'dan Yunanistan'a eleştiriler ve baskılar gelmeye başlamıştır. Azınlık haklarında bazı sınırlı ama olumlu değişikliklere gidilmesi Yunanistan'ın Avrupalılaşma çabasına girmesiyle paralel ilerlemiştir.

1990'larla beraber başlayan olumlu düzenlemeler, 1996 yılında Simitis Hükümeti'inin Avrupalılaşma çabalarına paralel olarak hızlanmıştır. Simitis'in hedefi Yunanistan'ı Avrupa'nın çevre ülkesi olmaktan çıkarıp, Avrupa'nın merkezine taşımaktır. Bu amaç doğrultusunda dış politikada milliyetçi söylemden uzaklaşarak, komşularıyla sorunlarını çözmüş, uzlaşmacı ve Avrupalı bir Yunanistan'a ulaşmak istiyordu. Her ne kadar görevinin ilk yıllarında partisi içindeki milliyetçi kanadın da etkisiyle Türkiye ile büyük krizler (Kardak Krizi 1996, Öcalan Krizi 1999) yaşansa da, uzun vadede Türkiye'nin $A B$ üyeliğini destekleyen ve sorunları $A B$ kanalıyla çözmek isteyen bir anlayış benimsenmiștir. ${ }^{4}$ Depremin de etkisiyle Türkiye ile yakınlașma süreci başlamıştır.

Yunanistan'ın Avrupalılaşma süreci bir modernleşme süreci olarak da adlandırılabilir. 1996'da iktidar gelen modernleşme yanlıları, ülkeyi Avrupa normlarına ve değerlerine uygun olarak hareket eden bir ülkeye dönüştürmeyi hedeflemişlerdir. Bu bağlamda Yunanistan'ın Avrupalılaşması “istenilen -

\footnotetext{
${ }^{4}$ Bakınız: Çakmak, G. (2012). The Europeanization of Greek Foreign Policy: Progress, Challenges and Strategies (Yayımlanmamış Doktora Tezi) Yeditepe Üniversitesi Sosyal Bilimler Enstitüsü, İstanbul.
} 
planlanmış Avrupalılaşma" sınıflandırması kapsamında değerlendirilebilir. Dönemin siyasi aktörleri ülkede hızlı bir reform süreci başlatmış ve Avrupalılaşmayı modernleşme ile eş anlamlı olarak değerlendirmişlerdir. $\mathrm{Bu}$ dönemde Yunanistan yönetiminde modernleşme hedefiyle hareket eden siyasi elitler bulunmaktadır ve bu yönüyle de Yunanistan'ın Avrupalılaşma süreci Ioakimidis'in sınıflandırmasına uygun düşmektedir. Avrupa normlarını kopyalamak anlamına da gelen "İstenilen- Planlanmış Avrupalılaşma" tam da bu özelliğiyle Yunanistan'daki süreci açıklamaktadır. Azınlık haklarında yapılan bazı olumlu değişiklikler ve gelişmeler de, Avrupa normlarının uygulanmasına yönelik faaliyetler olarak bu sürecin uzantısı niteliğinde değerlendirilebilir.

Bu modernleşme hareketi doğrultusunda Azınlık haklarında yapılan bazı iyileștirmeler ve yapılan reformlar önemli olmakla beraber azınlık mensuplarının beklentilerini karşılamaktan uzaktır. Vatandaşlık Yasasının 19. Maddesinin kaldırılması, eğitim alanında bazı olumlu düzenlemeler yapılması, kâğıt üzerinde de olsa eşit vatandaşlık vurgusunun yapılması, bölgesel yönetimlerin güçlendirilmesi önemli adımlar olarak görülebilir. Tüm yapılan olumlu düzenlemelere rağmen, Yunanistan'da azınlık hakları haklarına yönelik ihlaller ve kısıtlamalar mevcuttur. Batı Trakya Türk azınlığının çözüm bekleyen önemli sorunları bulunmaktadır. Özellikle etnik kimliğin reddi, din ve inanç hürriyeti konularında mağduriyetler devam etmektedir. 19. Madde sebebiyle vatandaşlıklarını kaybetmiş insanların mağduriyetleri de devam etmektedir. Vatandaşlıklarını geri kazanmaya çalışan insanları uzun, maliyetli ve sancılı bir yargı süreci beklemektedir. Bu süreci aşarak vatandaşlığını geri kazanan azınlık mensuplarının sayısı tam olarak bilinmemekle beraber sembolik düzeydedir.

Aynı zamanda Yunanistan'ın içinde bulunduğu ekonomik kriz azınlık mensuplarını olumsuz etkilemiş, uzun yıllardır süregelen ișsizlik ve istihdam konularındaki sıkıntıları tetiklemiştir.

Ayrıca krizle gittikçe tetiklenen aşırı milliyetçi oluşumlar her ne kadar bölgede Yunanistan'ın diğer bölgelerindeki kadar destekçi bulamasa da, ileriki dönemde azınlık için ciddi bir tehdit oluşturma potansiyeline sahiptir. Azınlığın yoğun olduğu bölgelerde aşırı Yunan milliyetçileri tarafından düzenlenen yürüyüşler ve eylemler tehlikenin boyutunu gözler önüne sermektedir.

\section{KAYNAKÇA}

AB Vizyonu. (t.y.). Batı Trakya'daki Müslüman Azınlık Cocuklarına Yönelik Eğitim Refomu Boğaziçi'nde tartışıldı. Erişim tarihi: 02.10.2016, http://www.abvizyonu.com/bati-trakyadaki-musluman-azinlik-cocuklarinayonelik-egitim-reformu-bogazicinde-tartisildi.html

Anadolu Ajansı (AA). (08.03.2018). Gümülcine seçilmiş müftüsüne 'makamı gasp' suçlaması. Erişim tarihi: 13.03.2018, https://aa.com.tr/tr/dunya /gumulcine-secilmis-muftusune-makami-gasp-suclamasi/1083384 
ANAGNOSTOU, D. (2005). Deepening democracy or defending the nation? The europeanisation of minority rights and Greek citizenship. West European Politics , Cilt 28 (2), s. 335-357.

ANAGNOSTOU, D., TRIANDAFYLLIDOU, A. (2007). The Muslim of Western thrace, Greece. Recommendations for regional development strategies. Hellenic Foundation for European and Foreign Policy. Erişim tarihi: 20.10.2016, http://www.eliamep.gr/old/eliamep/files/Policyreport Thrace_English_17_0 ctober 2007.pdf

ARI, K. (1995). Türkiye'ye Zorunlu Göç (1923-1925). İstanbul: Tarih Vakfı Yurt Yayınları.

Avrupa Batı Trakya Türk Federasyonu (ABTTF). (16.06.2014). ABTTF Birleşmiş Milletler'de Yunanistan'da seçim barajı sorununu gündeme taşıdı. Erișim tarihi: 03.02.2018, https://www.abttf.org/html/index.php?link=detay\&id=5136\&grup=4\&arsiv=0

Avrupa Birliği Anayasası. (t.y.). Erişim tarihi: 01.02.2018, http://europa.eu/eu-law/decisionmaking/treaties/pdf/treaty_establishing a constitution for europe/treaty establishing a constitution for europe en.pdf

Avrupa Komisyonu. (t.y.) Eurobarometer: Avrupa Birliği Kamuoyu Araştırmaları, No 24,25,26. Brüksel: Avrupa Komisyonu

Avrupa Konseyi. (t.y.). Etnik Azınlıkların Korunmasına İlişkin Çerçeve Sözleşmesi Metni. Erişim tarihi: 22.01.2018, http://conventions.coe.int/Treaty/ en/Treaties/Html/157.htm

AYKOÇ, E. (2009). Türkiye ve Yunanistan’ın Azınlık Politikaları: İkili İlişkiler, Ulusçuluklar ve Azınlık Hakları Ekseninde Karşılaştırmalı Bir Inceleme (Yayımlanmamış Doktora Tezi). İstanbul Üniversitesi Sosyal Bilimler Enstitüsü, İstanbul.

Bat Trakya Online. (t.y.). Vatandaşlıktan Çıkarma. Erişim tarihi: 20.01.2018, http://www.batitrakya.org/bati-trakya/insan-haklari/ vatandasliktan-cikarma.html

Bat Trakya'nın Sesi. (1988, Mart-Nisan). Federal Alman Yürüyüşü.

Batı Trakya Türkleri Dayanışma Derneği. (t.y.). Batı Trakya Türklerinin Sorunları. Erişim tarihi: 05.01.2018, http://www.bttdd.org.tr/sorunlarimiz/ bati-trakya-turklerinin-sorunlari.html

Batı Trakya Türkleri Dayanıșma Derneği Bursa Şubesi. (22.04.2009). Eğitim Sorunu. Erişim tarihi: 17.07.2018, http://www.bttddbursa.org/index. php?option $=$ com_content $\&$ view $=$ article \&id=81\&Itemid $=84$

CLOGG, R. (1993). The pasok phenomenon. Greece, 1981-1989: The populist decade. Londra: Macmillan Press.

CLOGG, R. (2002). Concise History of Greece. Cambridge: Cambridge University Press.

ÇELIKMEN, B. (2010). Azınlık Hakları ve Avrupa Birliği Kapsamında Batı Trakya Türklerinin Sorunları (Yayımlanmamış Yüksek Lisans Tezi). İstanbul Üniversitesi Sosyal Bilimler Enstitüsü, İstanbul.

ECONOMIDES, S. (2005). The europeanisation of Greek foreign policy. West European Politics, Cilt 28 (2). 
FEATHERSTONE, K. (1998). Europeanization and the centre periphery: The case of Greece in the 1990s. South European Society and Politics, Cilt 3 (1).

GRIORIADIS, I. N. (2008). On the europeanization of minority rights protection: comparing the cases of Greece and Turkey. Mediterranean Politics, Cilt 13 (1), s. 23-41.

Gündem Gazetesi. (16.03.2017). Müftü Ibrahim Şerif 'makam gaspı' iddiasılla suçlanıyor. Erişim tarihi: 10.01.2018, http://www.gundemgazetesi.com/haber/detay/2803

Gündem. (12.11.1996a).

Gündem. (19.11.1996b).

Gündem. (24.12.1996c)

Gündem. (21.01.1997a).

Gündem. (17.06.1997b).

Gündem. (25.06. 1997c).

Gündem. (05.10.1999).

Gündem. (04.07.2000).

HAYRULLAH, P., HÜSEYINOĞLU, A., KABZA, C. (2014). A report on Western thrace Turkish minority. Komotini: PEKEM Research Center.

HIRSCHON, R. (2005). Ege'yi Geçerken: 1923 Türk-Yunan Zorunlu Nüfus Mübadelesi. İstanbul: İstanbul Bilgi Üniversitesi Yayınları.

IOAKIMIDIS, P. C. (2000). The europeanization of Greece: An overall Assessment. South European Society and Politics, Cilt 5 (2).

IOAKIMIDIS, P. C. (2001). The europeanization of Greece: An overall assessment. Europeanization and the southern periphery. Londra: Frank Cass.

İSMAIL, A. (2012) Yunanistan'da Azınlık Hakları: Batı Trakya Türk Azınlığı Örneği (Yayımlanmamış Yüksek Lisans Tezi). Ankara Üniversitesi Sosyal Bilimler Enstitüsü, Ankara.

KERIDIS, D. (2006). Earthquakes, diplomacy and new thinking in foreign policy. The Fletcher Forum of World Affair's (30).

LYRINTZIS, C. (1993). PASOK in power: From 'change' to disenchanment. Greece, 1981-1989: The populist decade. Londra: Macmillan Press.

MEMIŞOĞLU, F. (2007). The European Union's minority rights policy and its impact on the development of minority rights protection in Greece. H. 0. Institute (Dü.), Contemporary Greece: Structures, Context and Challenges. Erişim tarihi: 23.01.2018 http://grammatikhilfe.com/europeanInstitute/research/ hellenicObservatory/pdf/3rd_Symposium/PAPERS/MEMISOGLOU_FULYA.pdf

NURİĞLLU, F. (03.06.1997). Avrupa günlüğü. Gündem.

NURİĞLU, F. (09.11.1999). Avrupa günlüğü. Gündem.

ONAR, N. F., ÖZGÜNEŞ, M. (2010). Europeanization of Greek and Turkish minority policies. International Journal on Minority and Group Rights, Cilt 17 (1), s. 111-136.

RUMELILİ, B. (2004, Ocak). The European Union's impact on the GreekTurkish conflict: A review of the literature. Working Papers Series in EU Border Conflicts Studies (6). 
SCHWELLNUS, G. (2001). Much ado about nothing? Minority protection and the EU charter of fundamental rights". Constitutionalismw eb-Papers, ConWEB (5). Erişim tarihi: 20.01.2018, http://www.qub.ac.uk/schools/Schoolof PoliticsInternationalStudiesandPhilosophy/FileStore/ConWEBFiles/Filetouplo ad,38355,en.pdf

SIEGL, E. (2002). Greek-Turkish relations- continutiy or change?

Perspectives: Central European Review of International Affairs (18), s. 40-52.

VERNEY, S. (1993). From the special relationship to europeanism:

PASOK and the European Community, 1981-89. Greece, 1981-1989: The populist decade. Londra: St. Martin Press.

WONG, R. (2011). Europeanization of foreign policy. International relations and the European Union (s. 149-170). Oxford: Oxford UP.

Yankı. (27.05.1988). Açlık Grevi.

YILDIRIM, O. (2006). Diploması ve Göç: Türk-Yunan Nüfus Mübadelesinin Öteki Yüzü. İstanbul: İstanbul Bilgi Üniversitesi Yayınları.

\section{Summary}

The aim of this study is to examine the role of Europeanization and European Institutions on the liberalization of minority rights in Greece starting with the 1990s. The Turkish Muslims Minority who had been given the legal status of minority by the Lausanne Treaty endured discriminative practices and human right violations by the Greek state and under the Greek governments.

Despite the fact that Greece became the member of the European Community in 1981 and passed through a period of democratization and spirit of tolerance in public sphere, the Turkish Muslim in Western Thrace kept facing with numerous human rights violations. These systematic violations led the politicization of the Minority. Especially, the Minority members and the minority associations in Germany organized several marches and protests in order to demonstrate the discriminative policies of the Greek government and the state. In the late 1990s, the human right record of Greece remained weak and the European Union and the Council of Europe put significant pressure on Greece to improve the conditions for minorities.

By 1990s, the European Community was transformed into a political union where the European norms and values were strongly emphasized. Liberalization and improvement in minority rights in Greece started in the early 1990s as a result of the growing international attention to minority rights in the post-Cold War period and the modernization, namely the Europeanization efforts of the then Greek government. Despite the existing problems of the Minority, Simitis government which came to power with an enthusiasm for Europeanization created more liberal conditions for the minority that resulted in positive changes in some of the discriminative practices such as limitations on the renovations of the mosques and houses, restrains on receiving licenses for cars and tractors, and 
getting bank-loans. In 1998, particularly after the heavy pressure and criticism from the Council of Europe, Greece removed the Article 19 of the Citizenship Code that gave state authorities the 'discretion to rescind Greek citizenship from nonethnic Greeks who left the country with no intention of returning, and which was in conflict with the principle of equality of the Greek Constitution. However, people who have lost their citizenship due to Article 19 have never been given the right to regain citizenship automatically since 1998.

As a result, after 1996, Greek political elites started to use more civic language concerning citizenship issues. Simitis's Foreign Minister Papandreou is a good example with his following statement: 'No one doubts that there are many Muslims of Turkish origin. Of course, the Treaties [of Lausanne] mention only Muslims. If no one contests the present borders, I could not care less if one calls himself a Muslim or a Turk, a Bulgarian or a Pomak' (Grigoriadis, 2008, s. 29). Using the word "Turk" referring to minority members was a significant progress for Greek politics.

The acceleration of Europeanization in Greece led to the adaptation of European values and norms including the notion of respect for minority rights. The repressive measures on the minorities were eased with the enthusiasm of Europeanization. However, despite the softening of discriminative measures and repressive policies, the fundamental problems of Western Thrace Turks in the realm of group-based rights emanating from their officially-recognized minority status, still persist as of 2018. 